CLINICAL STUDY

\title{
Serum concentrations and expressions of serum amyloid $A$ and leptin in adipose tissue are interrelated: the Genobin Study
}

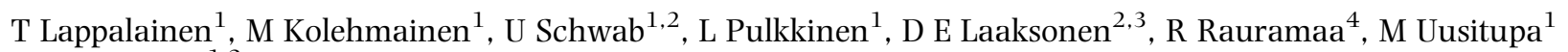 \\ and H Gylling ${ }^{1,2}$ \\ ${ }^{1}$ Department of Clinical Nutrition and Food and Health Research Center, University of Kuopio, PO Box 1627, FIN-70211 Kuopio, Finland, ${ }^{2}$ Institute of \\ Clinical Medicine, Internal Medicine, Kuopio University Hospital, PO Box 1777, FIN-70211 Kuopio, Finland, ${ }^{3}$ Department of Physiology and ${ }^{4}$ Kuopio \\ Research Institute of Exercise Medicine, University of Kuopio, PO Box 1627, FIN-70211 Kuopio, Finland \\ (Correspondence should be addressed to T Lappalainen; Email: tiina.lappalainen@uku.fi)
}

\begin{abstract}
Objective: Serum amyloid A (SAA) is a novel link between increased adipose tissue mass and low-grade inflammation in obesity. Little is known about the factors regulating its serum concentration and mRNA levels. We investigated the association between SAA and leptin in obese and normal weight subjects and analyzed the effect of weight reduction on serum SAA concentration and gene expression in adipose tissue of the obese subjects.

Methods: Seventy-five obese subjects ( $60 \pm 7$ years, body mass index (BMI) $32.9 \pm 2.8 \mathrm{~kg} / \mathrm{m}^{2}$, mean \pm s.D.) with impaired fasting plasma glucose or impaired glucose tolerance and other features of metabolic syndrome, and 11 normal weight control subjects ( $48 \pm 9$ years, BMI $23.7 \pm 1.9 \mathrm{~kg} / \mathrm{m}^{2}$ ) were studied at the baseline. Twenty-eight obese subjects underwent a 12-week intensive weight reduction program followed by 5 months of weight maintenance. Blood samples and abdominal s.c. adipose tissue biopsies were taken at the baseline and after the follow-up. Gene expression was studied using real-time quantitative PCR.

Results: The gene expressions in women and serum concentrations of leptin and SAA were interrelated independently of body fat mass in the obese subjects $(r=0.54, P=0.001 ; r=0.24, P=0.039$ respectively). In multiple linear regression analyses, leptin mRNA explained $38 \%$ of the variance in SAA mRNA $(P=0.002)$ in the obese women. Weight loss of at least 5\% increased SAA mRNA expression by 48 and $36 \%$ in men and women, but serum SAA concentrations did not change.

Conclusions: The association between SAA and leptin suggests an interaction between these two adipokines, which may have implications in inflammatory processes related to obesity and the metabolic syndrome.
\end{abstract}

European Journal of Endocrinology 158 333-341

\section{Introduction}

Obesity is characterized by chronic low-grade inflammation in the adipose tissue (1). White adipose tissue produces a wide range of inflammatory and other bioactive molecules. Some of these adipokines are linked to the immune system or acute phase response, such as tumor necrosis factor- $\alpha$ (TNF- $\alpha$ ), interleukin-6 (IL-6), high-sensitive C-reactive protein (hs-CRP), and serum amyloid A (SAA). These adipokines may contribute to comorbidities present in obesity, including features of the metabolic syndrome, type 2 diabetes, and cardiovascular diseases (2).

In short-term studies, weight loss has decreased both the concentration of inflammatory markers in the serum and their gene expression in the adipose tissue $(3,4)$. The improvement has mainly been detected after drastic weight loss during negative energy balance and marked fat mobilization $(3,5,6)$. Knowledge of the long-term effects of weight reduction on adipokines is still limited, and the findings have not been uniform. For example, in a recent study by Salas-Salvado et al. (7), a weight loss of $8.8 \%$ over a 6 -week period increased the expression of IL-6 and TNF- $\alpha$ in s.c. adipose tissue, suggesting that weight loss could actually have proinflammatory effects.

One of the most recent findings concerning adipokines deals with SAA that is synthesized in response to infection, inflammation, injury, and stress (8). The adipose tissue is a major site for the production of SAA providing a new link between enhanced adipose tissue mass and the low-grade inflammation state seen in obesity. The SAA may also contribute to dyslipidemia $(9,10)$ and replaces apolipoprotein A-1 (apoA-I) in highdensity lipoprotein (HDL) cholesterol, thus possibly inhibiting reverse cholesterol transport $(8,11)$. SAA may also modulate lecithin-cholesterol-acyltransferase activity (12). However, the biological function of SAA 
and its role in obesity and lipid and glucose metabolism are not yet established.

The serum concentration and mRNA expression of SAA have been reported to be higher in obese than in lean subjects (13). Sjöholm et al. (8) observed higher SAA mRNA levels in women than men. Furthermore, positive associations have been demonstrated with SAA and adiposity markers and hs-CRP $(5,6,8)$. Therefore, at least in morbid obesity, SAA is a consistent marker of adiposity-induced low-grade inflammation (6). It appears that SAA expression is regulated by fat mass, because weight reduction has decreased the SAA concentrations and its mRNA levels in the adipose tissue $(8,13)$. Accordingly, based on these findings, we were interested to investigate long-term impact of modest weight loss on the SAA concentration and the mRNA level in adipose tissue.

Leptin, the best-known adipocyte-derived signaling molecule is secreted by adipocytes and it may have effects on inflammation and SAA production. Leptin concentration and gene expression levels are proportional to total adipose mass and decrease after weight loss $(14,15,16)$. As of now, the association between SAA concentration and leptin has been investigated only in two studies $(5,17)$. The significant associations disappeared after adjustment for body fat or body mass index (BMI) suggesting that the association is attributable to adiposity. Leptin may act as a proinflammatory cytokine with direct actions on the immune-inflammatory response (18). Therefore, leptin could modulate SAA production, but this has not been proved.

To this end, we sought to investigate the serum levels and gene expressions of SAA and leptin in s.c. adipose tissue in abdominally obese men and women compared with that of normal weight control subjects. Furthermore, the long-term impact of modest weight reduction on these factors was investigated.

\section{Materials and methods}

\section{Subjects}

Seventy-five 40- to 70-year-old men and women were recruited for the study. The subjects were overweight or obese (BMI $28-40 \mathrm{~kg} / \mathrm{m}^{2}$ ), and they had impaired fasting glycemia (IFG; fasting plasma glucose concentration $5.6-7.0 \mathrm{mmol} / \mathrm{l}$ ), or impaired glucose tolerance (IGT; 2-h plasma glucose concentration $7.8-11.0 \mathrm{mmol} / \mathrm{l}$ ), and at least two other features of the metabolic syndrome according to the Adult Treatment Panel III criteria (19) as modified by American Heart Association (20): waist circumference $>102 \mathrm{~cm}$ (males), $>88 \mathrm{~cm}$ (females); fasting serum triacylglycerol concentration $\geq 1.7 \mathrm{mmol} / \mathrm{l}$; fasting serum HDL cholesterol $<1.0 \mathrm{mmol} / \mathrm{l}$ (males), $<1.3 \mathrm{mmol} / \mathrm{l}$ (females); blood pressure $\geq 130 / 80 \mathrm{mmHg}$. Of the participants,
8 subjects smoked regularly, 13 women were premenopausal and 33 postmenopausal, of whom 11 had hormone replacement therapy. Seventeen subjects had used lipid-lowering drugs with unchanged doses for at least 1 year. In addition, 36 subjects had used antihypertensive medication. All medications were maintained during the study.

After the baseline analysis, the obese subjects were randomized to one of the following groups: a weight reduction group $(n=28)$, an aerobic exercise group $(n=15)$, a resistance training group $(n=14)$, or an obese control group $(n=18)$. Subjects were matched for age, gender, BMI, and the status of glucose metabolism (IFG, IGT, and type 2 diabetes). There was no significant difference in any of the variables shown in Table 1 among the groups of obese subjects (data not shown). In addition, 11 normal weight healthy subjects ( 7 women and 4 men) were included as normal weight control subjects. Since there were no significant changes in anthropometric measurements, glucose metabolism, or serum lipid profile during the intervention in physical exercise groups, only the weight reduction and control groups were studied further. The Ethics Committee of the District Hospital Region of Northern Savo approved the study plan. All participants volunteered for the study and gave their written informed consent.

\section{Study design}

The duration of the study varied between 32 and 38 weeks (mean duration $33.3 \pm 1.1$ weeks). After the baseline measurements, the weight reduction group had a 12-week intensive weight reduction period during which they followed detailed instructions given by a clinical nutritionist, based on a 4-day dietary record and an interview. The subjects were asked to maintain their habitual level of physical exercise. During the period between weeks 12 and 33 the minimum aim was to maintain the reduced weight achieved and appointments with a nutritionist were organized if needed. The control group was asked not to change their lifestyle habits.

Body height was measured at the beginning of the intervention, and measurements for body weight, body composition, and waist circumference were performed during 0-33 weeks. At weeks 0 and 33, 12-h fasting blood samples were drawn to determine the concentrations of serum total and HDL cholesterol and serum triglycerides, plasma glucose and serum insulin, and those of the adipokines (SAA, IL- 6 , TNF- $\alpha$, hs-CRP, adiponectin, and leptin). Waist circumference was measured halfway between the lower rib and iliac crest with an accuracy of $0.1 \mathrm{~cm}$. Body weight was measured with digital scale SECA 880 (Vogel\&Halke, Hamburg, Germany), and body composition with bioelectrical impedance by STA/BIA Body Composition Analyzer (Akern Bioresearch Srl, Firenze, Italy). 
Table 1 Baseline characteristics of the study subjects ${ }^{a}$.

\begin{tabular}{|c|c|c|c|}
\hline Variables & Obese subjects $(n=75)$ & Normal weight control subjects $(n=11)$ & $\boldsymbol{P}^{\mathrm{b}}$ \\
\hline Gender (M/F) & $37 / 38$ & $4 / 7$ & \\
\hline Age (year) & $60 \pm 6.6$ & $48 \pm 8.6$ & $<0.001^{\mathrm{c}}$ \\
\hline Weight (kg) & $92.6 \pm 12.8$ & $69.1 \pm 12.1$ & $<0.001$ \\
\hline BMI $\left(\mathrm{kg} / \mathrm{m}^{2}\right)$ & $32.9 \pm 2.8$ & $23.7 \pm 1.9$ & $<0.001$ \\
\hline \multicolumn{4}{|l|}{ Blood pressure $(\mathrm{mmHg})$} \\
\hline Systolic & $137 \pm 13$ & $118 \pm 11$ & 0.003 \\
\hline Diastolic & $89 \pm 10$ & $83 \pm 10$ & NS \\
\hline Waist circumference $(\mathrm{cm})$ & $109 \pm 9$ & $84 \pm 8$ & $<0.001$ \\
\hline Body fat $(\%)$ & $37.8 \pm 7.4$ & $26.7 \pm 6.2$ & 0.003 \\
\hline Body fat (kg) & $34.9 \pm 7.9$ & $18.5 \pm 5.4$ & $<0.001$ \\
\hline Adipocyte cell size (pl) & $705 \pm 325$ & $426 \pm 251$ & 0.001 \\
\hline Serum cholesterol $(\mathrm{mmol} / \mathrm{l})$ & $5.3 \pm 1.1$ & $5.3 \pm 0.3$ & NS \\
\hline HDL cholesterol (mmol/l) & $1.25 \pm 0.23$ & $1.44 \pm 0.31$ & 0.006 \\
\hline Apolipoprotein A-I (g/l) & $1.46 \pm 0.17$ & $1.47 \pm 0.20$ & NS \\
\hline Serum triglycerides $(\mathrm{mmol} / \mathrm{l})$ & $1.64 \pm 0.78$ & $0.96 \pm 0.36$ & 0.019 \\
\hline Plasma glucose $(\mathrm{mmol} / \mathrm{l})$ & $6.4 \pm 0.5$ & $5.3 \pm 0.4$ & $<0.001$ \\
\hline Serum insulin $(\mathrm{mU} / \mathrm{l})$ & $12.6 \pm 7.6$ & $5.9 \pm 3.1$ & 0.004 \\
\hline $\mathrm{S}_{\mathrm{I}}\left(\mathrm{mU} / \mathrm{I}^{-1} \times \mathrm{min}^{-1}\right)$ & $2.17 \pm 1.10$ & $4.74 \pm 0.91(n=4)$ & 0.001 \\
\hline Serum amyloid $\mathrm{A}(\mu \mathrm{g} / \mathrm{ml})$ & $26.75 \pm 25.32$ & $9.64 \pm 7.30$ & 0.008 \\
\hline Serum leptin $(\mathrm{ng} / \mathrm{ml})$ & $21.04 \pm 12.31$ & $6.94 \pm 4.33$ & 0.002 \\
\hline C-reactive protein (mg/l) & $3.18 \pm 2.86$ & $1.08 \pm 0.86$ & 0.088 \\
\hline TNF- $\alpha(\mathrm{pg} / \mathrm{ml})$ & $2.21 \pm 2.70$ & $1.90 \pm 1.83$ & NS \\
\hline IL-6 (pg/ml) & $2.95 \pm 2.26$ & $1.35 \pm 1.23$ & 0.048 \\
\hline Adiponectin $(\mu \mathrm{g} / \mathrm{ml})$ & $6.03 \pm 2.88$ & $9.00 \pm 6.04$ & 0.011 \\
\hline
\end{tabular}

${ }^{a}$ Values are mean \pm s.D.

${ }^{\mathrm{b}}$ GLM univariate adjusted for age.

'Student's $t$-test.

$\mathrm{S}_{\mathrm{I}}$, insulin sensitivity index; TNF- $\alpha$, tumor necrosis factor $\alpha$; IL-6, interleukin-6.

The s.c. abdominal fat biopsies were taken at the baseline and after the intervention, and the mRNAs of SAA, leptin, adiponectin, and TNF- $\alpha$ of the biopsies were assayed. Normal weight control subjects $(n=11)$ visited the laboratory once for anthropometric measurements, fasting blood samples, adipose tissue biopsy, and oral glucose tolerance test. Adipose tissue biopsy was successfully drawn from ten normal weight subjects.

\section{Biochemical analyses}

Plasma glucose concentration was measured with the hexokinase method (Thermo Clinical Labsystems, Vantaa, Finland), and insulin with a chemiluminescence sandwich method (ACS, Bayer/Chiron). The frequently sampled intravenous glucose tolerance test was performed according to the minimal model method (21). The results were calculated by the Minimal Model Millennium software 6.02 (22). Total serum cholesterol and triglycerides, and HDL cholesterol after precipitation of apoprotein (apo) B were analyzed with enzymatic methods (CHOD-PAP and GPO-PAP, Roche Diagnostics) on Kone Pro Clinical Chemistry Analyzer (Thermo Clinical Labsystems, Konelab, Espoo, Finland). Serum apo-AI concentration was measured immunoturbidometrically (Thermo Electron Corp, Konelab 20XTi, Vantaa, Finland).

Hs-CRP was determined with Immage Immunochemistry System (Beckman Coulter, Fullerton, CA, USA).
The SAA concentrations were measured with an ELISA kit (Biosource International, Camarillo, CA, USA). The serum leptin concentration was measured with a commercial RIA kit (Linco Research Inc., St Louis, MO, USA). The adiponectin concentrations were measured with an ELISA kit (R\&D Systems Inc., MN, USA).

\section{Adipocyte cell size, RNA extraction, cDNA synthesis}

Adipose tissue samples for RNA extraction and cell size measurements were taken by a syringe from an s.c. abdominal adipose tissue under local anesthesia (lidocaine $10 \mathrm{mg} / \mathrm{ml}$ without epinephrine) after an overnight fast to collect $0.5-5 \mathrm{~g}$ of adipose tissue. Biopsies were washed twice with GIBCO phosphatebuffered saline (Invitrogen). Part of the sample was stored in RNAlater (Ambion, Austin, TX, USA) at $4{ }^{\circ} \mathrm{C}$ for RNA extraction. After $24 \mathrm{~h}$, RNAlater was removed and samples were stored at $-80^{\circ} \mathrm{C}$.

Adipocytes were isolated in the presence of collagenase $(0.5 \mathrm{mg} / \mathrm{ml})$ under constant shaking at $2 \mathrm{~Hz}$ at $37^{\circ} \mathrm{C}$ in buffer containing $125 \mathrm{mmol} / \mathrm{l} \mathrm{NaCl}, 5 \mathrm{mmol} / \mathrm{l}$ $\mathrm{KCl}, 1 \mathrm{mmol} / \mathrm{l} \mathrm{CaCl}_{2}, 2.5 \mathrm{mmol} / \mathrm{l} \mathrm{MgCl}_{2}, 1 \mathrm{mmol}$ $\mathrm{KH}_{2} \mathrm{PO}_{4}, 4 \mathrm{mmol} / \mathrm{l}$ glucose, $2 \%$ bovine serum albumin, and $25 \mathrm{mmol} / \mathrm{l}$ Tris at $\mathrm{pH} 7.4(23,24)$. After $60 \mathrm{~min}$ cells were filtered through nylon cloth and washed three times with the same buffer without collagenase. Direct microscopic determination of the adipose cell diameter 
was performed by placing an aliquot of cell suspension in the Bürker chamber and examining with light microscope (Olympus CH-2). The median diameter of 100-200 cells was used for the estimation of fat cell size.

Total RNA from adipose tissue was extracted using a TRIzol method followed by further purification with RNeasy Mini Kit columns according to the instructions provided by the manufacturers (Invitrogen and Qiagen). Five microgram of the total RNA were converted to firststrand cDNAs in $100 \mu \mathrm{l}$ reactions using random primers (high-capacity cDNA Archive Kit P/N 4322171, Applied Biosystems, Foster City, CA, USA).

\section{Real-time PCR analysis}

Real-time PCR (QPCR) analyses were performed using ABI Prism 7500 Real-Time PCR system using assays based on TaqMan chemistry and ABI Prism 7500 SDS software (Applied Biosystems). Because of the high homology between SAA1 and SAA2, the primers were designed to detect both isoforms. The expression of cyclophilin A1 was used as an endogenous control. Each PCR consisted of 6 ng cDNA, $1 \times$ Assay Mix, and $1 \times$ TaqMan Universal PCR Master Mix (Applied Biosystems). QPCR data were collected during each extension phase of the PCR. For the standard curve, all samples of obese subjects were pooled to generate a representative cDNA for standard dilutions. A standard curve with five concentrations $(0.5,1.5,6,18$, and $36 \mathrm{ng} / \mu \mathrm{l})$ and calibrator $(6 \mathrm{ng} / \mu \mathrm{l})$ were used on every plate and for every gene. This standard curve was used to determine the relative quantity of cDNA in each sample by comparison using methods described in the ABI Prism User Bulletin no. 2. The quantities on each plate were first corrected by the calibrator on the plate. Furthermore, the relative amount/plate was corrected with the corresponding values of endogenous control cyclophilin A1. Analyses for the relative quantity of specific gene before and after the intervention were analyzed in triplicates.

\section{Statistical analysis}

Statistical tests were performed using SPSS statistical software for Windows (version 14.0, SPSS Inc., Chigago, IL, USA). The normality of distributions of the variables was verified with the KolmogorovSmirnov test with Lilliefors correction. Logarithmic transformation was used when appropriate. The baseline differences in variables among the groups were analyzed using general linear model (GLM) for univariate analysis adjusted for age. The GLM for repeated measures was used for analyzing the interaction of time and group. If GLM was statistically significant $(P<0.05)$, independent samples $t$-test was used for analyzing comparisons between different groups, and paired samples $t$-test was used for comparing the baseline and endpoint variables within the study group. The correlations were calculated with the Pearson and Spearman methods. Partial correlations were calculated to control for confounding factors. Multiple linear regression analysis was used to assess the influence of age, percentage of fat, size of adipocyte, leptin mRNA, and TNF- $\alpha$ mRNA levels on the variation of SAA mRNA (dependent variable). In tables and figures unadjusted values are shown, but the statistics between obese subjects and normal weight control subjects are calculated with the age-adjusted values.

\section{Results}

\section{Baseline variables of the study group}

There was a significant difference in age between the 75 obese and 11 normal weight subjects, and thus the comparisons between these groups were adjusted for age (Table 1). As expected, the obese subjects showed significantly higher body weight, BMI, percentage of body fat, body fat mass (kg), waist circumference, adipocyte cell size, and fasting plasma glucose and serum insulin levels than the normal weight subjects. The serum concentration of triglycerides was higher, but HDL cholesterol was lower in the obese subjects than in the normal weight controls.

\section{Baseline serum values}

The obese subjects showed decreased concentration of adiponectin, increased concentrations of SAA, leptin, and IL- 6 , but not of hs-CRP and TNF- $\alpha$ when compared with normal weight control subjects (Table 1). In the obese subjects, a significant gender difference was found in SAA and leptin concentrations, such that in women the SAA concentration was $35.6 \pm 32.0 \mu \mathrm{g} / \mathrm{ml}$ and that of leptin $30.2 \pm 9.7 \mathrm{ng} / \mathrm{ml}$, whereas the respective values for men were $17.7 \pm 9.8 \mu \mathrm{g} / \mathrm{ml}$ and $11.7 \pm$ $5.9 \mathrm{ng} / \mathrm{ml}(P<0.001$ for both $)$. In normal weight subjects, serum leptin concentrations were also higher in women $(9.1 \pm 4.0 \mathrm{ng} / \mathrm{ml})$ than men $(3.1 \pm 0.8 \mathrm{ng} / \mathrm{ml}$, $P=0.017$ ), but SAA concentrations did not differ.

In the obese subjects, serum SAA concentration correlated positively with BMI, body fat mass (Table 2), and serum leptin (Fig. 1A). The latter association remained significant after adjustment for fat mass $(r=0.24, P=0.039)$ or hs-CRP $(r=0.28, P=0.015)$. In addition, SAA concentration was positively associated with hs-CRP (Table 2), but not with IL-6 or TNF- $\alpha$ (data not shown). Furthermore, serum concentrations of leptin and IL-6 were intercorrelated $(r=0.25$, $P=0.035)$. In women, SAA was negatively correlated with insulin sensitivity index $\left(\mathrm{S}_{\mathrm{I}}\right)$. However, when corrected for fat mass, the correlation was no longer statistically significant. The concentrations of SAA were not associated with total and HDL cholesterol or apo-AI levels. 
Table 2 Associations of serum amyloid A (SAA) concentration with other variables at baseline in the obese men and women and in normal weight subjects.

\begin{tabular}{|c|c|c|}
\hline & $r$ & $\boldsymbol{P}$ \\
\hline \multicolumn{3}{|l|}{ BMI } \\
\hline Obese subjects $(n=75)$ & 0.43 & $<0.001^{a}$ \\
\hline Men $(n=37)$ & 0.25 & $\mathrm{NS}(P=0.13)$ \\
\hline Women $(n=38)$ & 0.45 & 0.004 \\
\hline Normal weight subjects $(n=11)$ & 0.46 & NS $(0.16)^{b}$ \\
\hline \multicolumn{3}{|l|}{ Body fat mass $(\mathrm{kg})$} \\
\hline Obese subjects $(n=75)$ & 0.43 & $<0.001^{\mathrm{a}}$ \\
\hline Men $(n=37)$ & 0.12 & $\mathrm{NS}(P=0.47)$ \\
\hline Women $(n=38)$ & 0.53 & 0.001 \\
\hline Normal-weight subjects $(n=11)$ & 0.77 & $0.005^{\mathrm{a}}$ \\
\hline \multicolumn{3}{|l|}{ hs-CRP } \\
\hline Obese subjects $(n=75)$ & 0.51 & $<0.001^{\mathrm{b}}$ \\
\hline Men $(n=37)$ & 0.54 & 0.001 \\
\hline Women $(n=38)$ & 0.51 & 0.001 \\
\hline Normal weight subjects $(n=11)$ & 0.50 & NS $(0.11)^{b}$ \\
\hline \multicolumn{3}{|l|}{$\mathrm{S}_{\text {I }}\left(\left(\mathrm{mU} / /^{-1}\right.\right.$ per $\left.\left.\mathrm{min}\right)\right)$} \\
\hline Obese subjects $(n=75)$ & -0.08 & $\mathrm{NS}(P=0.53)^{\mathrm{b}}$ \\
\hline Men $(n=37)$ & 0.29 & $\mathrm{NS}(P=0.08)$ \\
\hline Women $(n=38)$ & -0.34 & 0.044 \\
\hline Normal weight subjects $(n=4)$ & -0.32 & NS $(0.68)^{b}$ \\
\hline \multicolumn{3}{|l|}{ SAA mRNA } \\
\hline Obese subjects $(n=75)$ & 0.37 & $0.001^{b}$ \\
\hline Men $(n=37)$ & 0.06 & NS $(P=0.75)$ \\
\hline Women $(n=38)$ & 0.22 & $\mathrm{NS}(P=0.20)$ \\
\hline Normal weight subjects $(n=10)$ & 0.68 & $0.031^{\mathrm{a}}$ \\
\hline
\end{tabular}

aSpearman's rank correlation coefficient.

bearson's correlation coefficient.

In the normal weight control subjects, serum SAA concentration correlated positively with serum leptin concentration (Fig. 1B) even after controlling for body fat mass $(r=0.82, P=0.003)$. Moreover, serum concentrations of leptin and IL-6 were intercorrelated $(r=0.64, P=0.035)$.

\section{mRNA expressions in adipose tissue at baseline}

The expression of both SAA $(108 \pm 71$ AU versus $26 \pm 19$ AU, $P=0.001)$ and leptin $(77 \pm 26$ vs $46 \pm 14, P<0.001)$ were higher in obese women than obese men. There was no gender difference in TNF- $\alpha$ gene expression ( $44 \pm 38$ $\mathrm{AU}$ in women and $45 \pm 45 \mathrm{AU}$ in men). In normal weight control subjects no differences between genders were found. Hormone replacement therapy, lipid lowering or anti-hypertensive drugs did not affect the SAA mRNA levels or the serum concentrations at the basal level. Moreover, there were no differences between non-smokers and regular smokers or between premenopausal and postmenopausal women in SAA levels.

In the obese subjects, there was a positive correlation between SAA mRNA levels and fasting SAA concentration (Table 2), body fat mass $(r=0.29, P=0.015)$, and adipocyte cell size $(r=0.31, P=0.008)$. There was also a positive association between the SAA mRNA and the serum leptin concentration $(r=0.59$, $P<0.001)$, which was independent of fat mass $(r=0.60, P<0.001)$. Furthermore, there was a positive association between the mRNA levels of SAA and leptin (Fig. 1C), also when adjusted for body fat $(r=0.63$, $P<0.001)$. When divided by gender the association was significant only for women $(r=0.54, P=0.001)$.

In the normal weight control subjects there was a significant correlation between the mRNAs of leptin and SAA (Fig. 1D), and the trend remained after adjustment for fat mass $(r=0.60, P=0.085)$. Furthermore, the SAA mRNA level and the serum leptin concentration were intercorrelated $(r=0.71, P=0.021)$ even after adjustment for fat mass $(r=0.71, P=0.034)$.

\section{Multiple regressions}

The variables explaining the variance of the mRNA levels of SAA were evaluated separately in men and women. In women, the linear regression analysis with SAA mRNA level as the independent variable and age, percentage of body fat, size of adipocytes, leptin mRNA, and TNF- $\alpha$ mRNA levels as the dependent variables, only leptin mRNA level significantly explained the variation of SAA $\left(R^{2}=0.38 ; P=0.002\right)$. In men, none of the variables explained the variance of the mRNA levels of SAA.

\section{Effect of weight reduction}

In the weight reduction group $(n=28)$, the 33-week intervention decreased body weight by $4.6 \pm 3.9 \mathrm{~kg}$ from $92.8 \pm 15.1$ to $88.2 \pm 13.6(P<0.001)$. The BMI was reduced from $32.9 \pm 3.2$ to $31.3 \pm 2.7 \mathrm{~kg} / \mathrm{m}^{2}$, waist circumference from $108 \pm 9$ to $105 \pm 8 \mathrm{~cm}$, fat mass from $34.7 \pm 8.9$ to $31.7 \pm 7.9 \mathrm{~kg}$, and serum leptin concentration from $20.5 \pm 11.3$ to $17.3 \pm 9.2 \mathrm{ng} / \mathrm{ml}$ $(P=0.001$ for all). No significant changes were detected in the obese control group. The SAA and leptin mRNA levels and serum leptin concentration were higher in women than men in the weight reduction and obese control groups at the baseline and after 33 weeks (Table 3). The overall change in SAA mRNA with time was significant between the weight reduction and obese control groups (Table 3). Further analysis indicated that the SAA mRNA level increased $(P=0.002)$ in the weight reduction group and in both women and men $(P=0.035 ; P=0.030$ respectively). The increase remained significant regardless of the use of different medications. Furthermore, the positive correlation between the SAA mRNA level and the serum SAA concentration remained significant $(r=0.38$, $P=0.001)$.

The overall change in serum leptin concentration with time differed between the weight reduction and obese control groups, but the reduction was significant only in women of the weight reduction group $(P=0.015)$. The changes between the groups in leptin mRNA, concentrations of SAA, and hs-CRP or adipocyte cell size were not significant. 

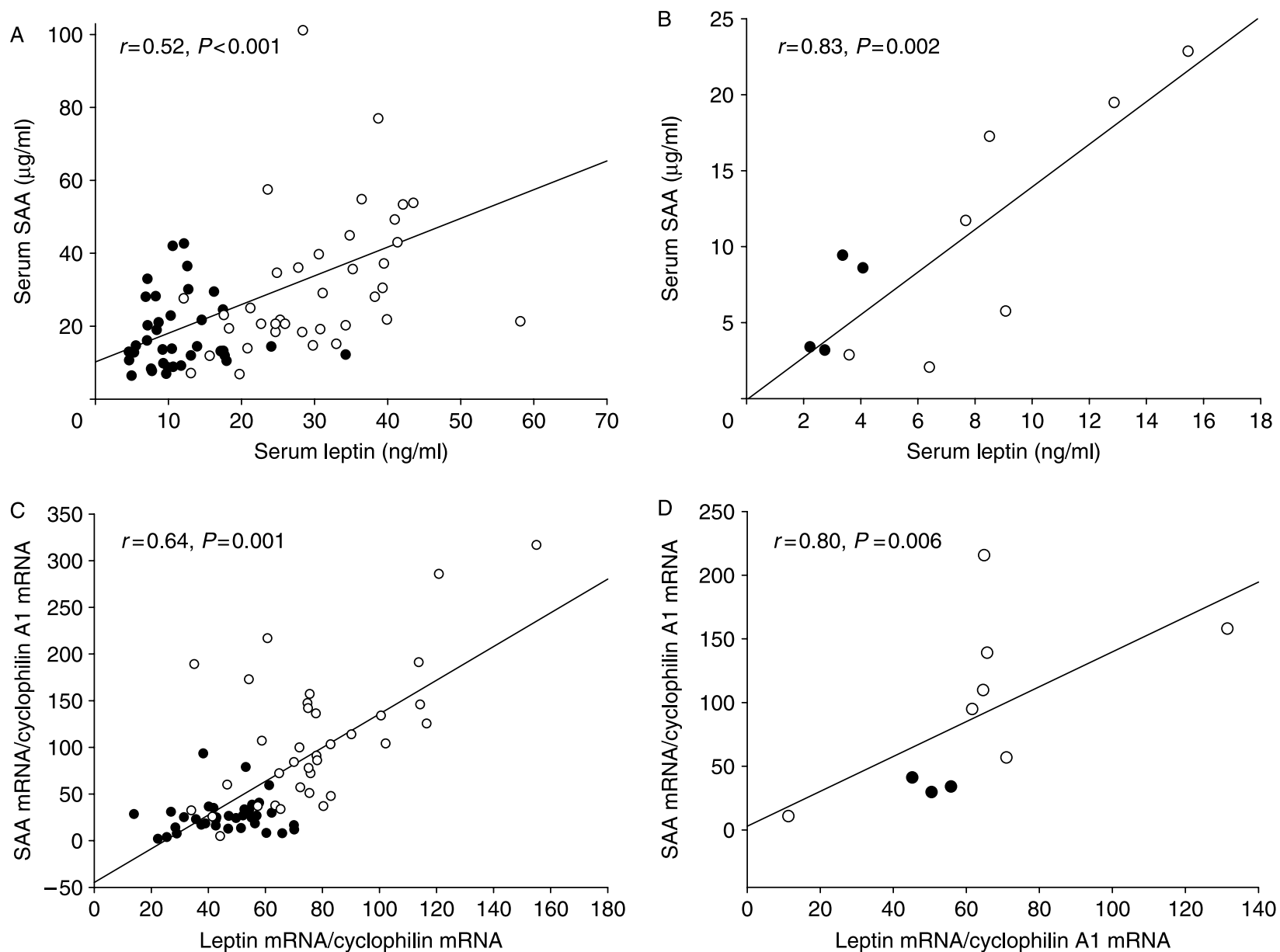

Figure 1 The association of serum amyloid $A$ and leptin concentrations in $(A) 75$ obese subjects $(r=0.52, P<0.001)$, and $(B) 11$ normal weight control subjects $(r=0.83, P=0.002)$, and the association of serum amyloid $A$ and leptin mRNA levels in $(C) 75$ obese subjects ( $r=0.64, P=0.001)$, and (D) 10 normal weight control subjects $(r=0.80, P=0.006)$ at the baseline. Black circles represent men and white represent women.

\section{Discussion}

The SAA and IL-6 were increased in these abdominally obese men and women with characteristics of the metabolic syndrome and disturbed insulin and glucose metabolism consistent with the presence of a low-grade inflammatory state. The major novel findings of this study were that serum concentrations of leptin and SAA were associated with each other independently of body fat mass in both obese and normal weight subjects. There was also a strong association between the gene expressions of SAA and leptin after correction for fat mass in the obese subjects, especially in women. Unexpectedly, a weight reduction with at least 5\% weight loss resulted in a seemingly paradoxical increase in SAA mRNA expression in an s.c. adipose tissue.

At the baseline, there was a gender difference among obese subjects with higher serum SAA and leptin concentrations and mRNA levels in women than men. The higher serum SAA concentration in women is a novel finding, but a gender difference in SAA mRNA level has been documented previously (8). The SAA mRNA expression has been reported in both the omental and s.c. adipose tissues $(5,13)$. However, in morbidly obese subjects the expression of SAA was found to be higher in s.c. than visceral adipose tissue (6). Accordingly, because women in general have relatively greater amounts of s.c. than visceral fat compared with men, the gender difference in SAA may be due to the regional difference in SAA gene expression. In multiple linear regression analyses, the size of adipocytes did not explain the SAA expression in women.

Our findings suggest a contribution of leptin expression to the SAA mRNA level or vice versa independently of body fat mass. The associations between serum concentrations of SAA and leptin found in both obese and lean subjects support a possible causal relationship. Little is known about the interaction between leptin and SAA, particularly in healthy normal weight subjects, and the mechanisms linking leptin and SAA are not clear. Both SAA and leptin are 
Table 3 Changes in serum amyloid A (SAA), leptin, high-sensitive C-reactive protein (hs-CRP) concentrations, adipocyte cell size and in gene expressions of SAA and leptin in the obese subjects with and without weight reduction ${ }^{\mathrm{a}}$.

\begin{tabular}{|c|c|c|c|c|c|}
\hline & \multicolumn{2}{|c|}{ Weight reduction group } & \multicolumn{2}{|c|}{ Obese control group } & \multirow[b]{2}{*}{$\boldsymbol{P}^{\mathrm{b}}$} \\
\hline & Men $(n=12)$ & Women $(n=16)$ & Men $(n=8)$ & Women $(n=10)$ & \\
\hline \multicolumn{6}{|l|}{ SAA $(\mu \mathrm{g} / \mathrm{ml})$} \\
\hline 0 week & $19.3 \pm 8.0$ & $33.1 \pm 42.4$ & $17.4 \pm 12.0$ & $31.8 \pm 21.9$ & \\
\hline $\begin{array}{l}33 \text { weeks } \\
\text { SAA mRNA }\end{array}$ & \multicolumn{4}{|c|}{ SAA mRNA (AU) } & NS \\
\hline 0 week & $21 \pm 8$ & $76 \pm 53^{*}$ & $46 \pm 27^{\dagger}$ & $130 \pm 80^{*}$ & \\
\hline 33 weeks & $31 \pm 26^{\ddagger}$ & $103 \pm 87^{\star, \neq}$ & $52 \pm 31$ & $143 \pm 72^{*}$ & 0.004 \\
\hline \multicolumn{6}{|c|}{ Serum leptin (ng/ml) } \\
\hline 0 week & $11.4 \pm 7.9$ & $27.4 \pm 8.3^{*}$ & $9.0 \pm 2.9$ & $29.5 \pm 9.4^{\star}$ & \\
\hline 33 weeks & $9.7 \pm 6.9$ & $23.1 \pm 6.0^{\star, \ddagger}$ & $9.0 \pm 3.2$ & $28.5 \pm 8.3^{*}$ & 0.005 \\
\hline \multicolumn{6}{|c|}{ Leptin mRNA (AU) } \\
\hline 0 week & $48 \pm 12$ & $68 \pm 20^{*}$ & $49 \pm 10$ & $80 \pm 22^{*}$ & \\
\hline 33 weeks & $48 \pm 11$ & $73 \pm 23^{*}$ & $55 \pm 10$ & $83 \pm 21^{*}$ & NS \\
\hline \multicolumn{6}{|c|}{ hs-CRP (mg/l) } \\
\hline 0 week & $3.68 \pm 2.55$ & $3.03 \pm 2.65$ & $1.57 \pm 0.95$ & $2.38 \pm 1.34$ & \\
\hline 33 weeks & $4.46 \pm 7.28$ & $2.40 \pm 2.39$ & $2.12 \pm 1.95$ & $2.55 \pm 1.47$ & NS \\
\hline \multicolumn{6}{|c|}{ Adipocyte cell size (pl) } \\
\hline 0 week & $533 \pm 225$ & $865 \pm 389^{*}$ & $494 \pm 359$ & $745 \pm 243$ & \\
\hline 33 weeks & $780 \pm 285$ & $719 \pm 363$ & $695 \pm 275$ & $762 \pm 391$ & NS \\
\hline
\end{tabular}

*Student's $t$-test for the gender difference within the group, $P<0.05 .{ }^{\dagger}$ GLM univariate for the difference between the weight reduction and control groups divided by gender, $P<0.05$. ${ }^{\ddagger}$ Paired samples $t$-test for the change within the groups, $P<0.05$.

${ }^{\mathrm{a}}$ Values are mean \pm S.D.

${ }^{\mathrm{b}}$ General linear model (GLM), effect of time.

predominantly expressed in adipocytes, which may in part explain the interaction. The SAA production is induced by the pro-inflammatory cytokines, TNF- $\alpha$, and IL-6 (25). Since leptin is known to induce both TNF- $\alpha$ and IL- 6 production, it is conceivable that SAA production is up-regulated by leptin via these cytokines (26). Supporting this hypothesis, we found an association between the concentrations of leptin and IL-6. Unfortunately, we were not able to measure IL-6 mRNA levels in s.c. adiposose tissue, probably due to regional variation in IL-6 expression, since the expression is higher in visceral than s.c. fat (27).

It is possible that leptin may also directly affect SAA synthesis in adipocytes. However, these signaling pathways in the adipose tissue are not well elucidated, and it should be borne in mind that the cross-sectional association of SAA and leptin does not permit conclusions on the directionality.

If leptin induces SAA production, it may provide a novel mechanistic link between obesity and the associated vascular complications. First, the SAA is a significant predictor of coronary artery disease risk in women, but the mechanism of the association is not comprehended (28). Secondly, there is also increasing evidence of an association between leptin and cardiovascular risk $(29,30)$. In obesity, both leptin and SAA are increased simultaneously, and this may even be associated with an additive increase in cardiovascular risk.

There are only few reports showing that leptin and hs-CRP concentrations are interrelated independently of adiposity markers in the obese and normal weight subjects (31-33). These findings suggest that leptin may modulate hs-CRP levels either directly or indirectly through inflammatory pathways in the immune system. We also looked for the expression of CRP mRNA in s.c. adipose tissue, but we did not find measurable quantities (data not shown). Previous findings on the presence of CRP mRNA in s.c. adipose tissue are conflicting $(8,34)$.

The 33-week intervention with at least 5\% weight loss increased mRNA expression of SAA in s.c. adipose tissue in both genders, even though the respective serum concentration was unchanged. This observation is in contrast to previous findings $(6,8)$. Discrepancies between these outcomes can be due to differences in study design. The subjects in the prior studies had been severely obese, and underwent very-low-calorie diet or bariatric surgery, resulting in a drastic short-term weight loss $(6,8)$. In the present study, however, the subjects were less obese, and the weight loss was modest. It may be that the 5-month follow-up period allows compensatory mechanisms to be up-regulated. More specific effects might have been found with samples obtained at week 12. However, the study was very demanding for the subjects, and it would have been too much to include a third adipose tissue biopsy in the protocol. In addition, it should be taken into account that concomitant gene expression changes in visceral adipose tissue remained unknown. Moreover, the hepatic contribution to SAA concentration is not known (13).

Taken together, the present data indicate that longterm modest weight reduction increased SAA mRNA 
expression in s.c. abdominal adipose tissue. Because the serum concentrations of SAA did not change, the clinical relevance of this finding needs to be evaluated further. In addition, our findings suggest a strong interaction between SAA and leptin expression at the mRNA level in adipose tissue in obese subjects. The body fat mass-independent associations between the serum concentrations of SAA and leptin found in normal weight and obese subjects support a possible causal relationship, which may have implications in inflammatory processes related to obesity and the metabolic syndrome.

\section{Acknowledgements}

The authors thank Ms Kaija Kettunen, Ms Päivi Turunen and Mr Tuomas Onnukka for skilful technical assistance. This study was supported by grants from the Academy of Finland (nr 209445; nr 211497), the Ministry of Education in Finland (nr 125/722/2003), the Finnish Foundation for Diabetes Research, the Sigrid Juselius Foundation, the Jenny and Antti Wihuri Foundation, Kuopio Doctoral Program of Medical Sciences, Faculty of Medicine, University of Kuopio, and the Finnish Graduate School on Applied Bioscience: Bioengineering, Food and Nutrition, Environment.

\section{References}

1 Trayhurn P. Endocrine and signalling role of adipose tissue: new perspectives on fat. Acta Physiologica Scandinavica 2005184 285-293.

2 Tilg H \& Moschen AR. Adipocytokines: mediators linking adipose tissue, inflammation and immunity. Nature Reviews. Immunology $20066772-783$.

3 Cottam DR, Mattar SG, Barinas-Mitchell E, Eid G, Kuller L, Kelley DE \& Schauer PR. The chronic inflammatory hypothesis for the morbidity associated with morbid obesity: implications and effects of weight loss. Obesity Surgery 2004 14 589-600.

4 Clement K, Viguerie N, Poitou C, Carette C, Pelloux V, Curat CA, Sicard A, Rome S, Benis A, Zucker JD, Vidal H, Laville M, Barsh GS, Basdevant A, Stich V, Cancello R \& Langin D. Weight loss regulates inflammation-related genes in white adipose tissue of obese subjects. FASEB Journal 200418 1657-1669.

5 Gomez-Ambrosi J, Salvador J, Rotellar F, Silva C, Catalan V, Rodriguez A, Jesus Gil M \& Fruhbeck G. Increased serum amyloid A concentrations in morbid obesity decrease after gastric bypass. Obesity Surgery 200616 262-269.

6 Poitou C, Coussieu C, Rouault C, Coupaye M, Cancello R, Bedel JF, Gouillon M, Bouillot JL, Oppert JM, Basdevant A \& Clément K. Serum amyloid A: a marker of adiposity-induced low-grade inflammation but not of metabolic status. Obesity 200614 309-318.

7 Salas-Salvado J, Bullo M, Garcia-Lorda P, Figueredo R, Del Castillo D, Bonada A \& Balanzà R. Subcutaneous adipose tissue cytokine production is not responsible for the restoration of systemic inflammation markers during weight loss. International Journal of Obesity $20063 \mathbf{3 0} 1714-1720$.

8 Sjöholm K, Palming J, Olofsson LE, Gummesson A, Svensson PA, Lystig TC, Jennische E, Brandberg J, Torgerson JS, Carlsson B \& Carlsson LM. A microarray search for genes predominantly expressed in human omental adipocytes: adipose tissue as a major production site of serum amyloid A. Journal of Clinical Endocrinology and Metabolism $2005902233-2239$.

9 Johnson BD, Kip KE, Marroquin OC, Ridker PM, Kelsey SF, Shaw LJ, Pepine CJ, Sharaf B, Bairey Merz CN, Sopko G, Olson MB, Reis SE \& National Heart, Lung, and Blood Institute. Serum amyloid A as a predictor of coronary artery disease and cardiovascular outcome in women: the National Heart, Lung, and Blood InstituteSponsored Women's Ischemia Syndrome Evaluation (WISE). Circulation 2004109 726-732.

10 Fyfe AI, Rothenberg LS, DeBeer FC, Cantor RM, Rotter JI \& Lusis AJ. Association between serum amyloid A proteins and coronary artery disease: evidence from two distinct arteriosclerotic processes. Circulation $1997962914-2919$.

11 Kisilevsky R \& Tam SP. Acute phase serum amyloid A, cholesterol metabolism, and cardiovascular disease. Pediatric Pathology and Molecular Medicine $200221291-305$.

12 Steinmetz A, Hocke G, Saile R, Puchois P \& Fruchart JC. Influence of serum amyloid A on cholesterol esterification in human plasma. Biochimica et Biophysica Acta 19891006 173-178.

13 Poitou C, Viguerie N, Cancello R, De Matteis R, Cinti S, Stich V, Coussieu C, Gauthier E, Courtine M, Zucker JD, Barsh GS, Saris W, Bruneval P, Basdevant A, Langin D \& Clément K. Serum amyloid A: production by human white adipocyte and regulation by obesity and nutrition. Diabetologia 200548 519-528.

14 Friedman JM \& Halaas JL. Leptin and the regulation of body weight in mammals. Nature 1998395 763-770.

15 Maffei M, Halaas J, Ravussin E, Pratley RE, Lee GH, Zhang Y, Fei H, Kim S, Lallone R, Ranganathan S, Kern PA \& Friedman JM. Leptin levels in human and rodent: measurement of plasma leptin and ob RNA in obese and weight-reduced subjects. Nature Medicine 1995 1 1155-1161.

16 Montague CT, Prins JB, Sanders L, Digby JE \& O’Rahilly S. Depotand sex-specific differences in human leptin mRNA expression: implications for the control of regional fat distribution. Diabetes 199746 342-347.

17 van Dielen FM, van't Veer C, Schols AM, Soeters PB, Buurman WA \& Greve JW. Increased leptin concentrations correlate with increased concentrations of inflammatory markers in morbidly obese individuals. International Journal of Obesity and Related Metabolic Disorders 200125 1759-1766.

18 Otero M, Lago R, Gomez R, Dieguez C, Lago F, Gomez-Reino J \& Gualillo O. Towards a pro-inflammatory and immunomodulatory emerging role of leptin. Rheumatology $200645944-950$.

19 Expert Panel on Detection, Evaluation, and Treatment of High Blood Cholesterol in Adults. Executive Summary of the Third Report of the NationalCholesterol Education Program (NCEP) Expert Panel on Detection, Evaluation, And Treatment of High Blood Cholesterol in Adults (Adult Treatment Panel III). Journal of the American Medical Association 2001285 2486-2497.

20 Grundy SM, Cleeman JI, Daniels SR, Donato KA, Eckel RH, Franklin BA, Gordon DJ, Krauss RM, Savage PJ, Smith SC Jr, Spertus JA \& Costa F. Diagnosis and management of the metabolic syndrome: an American Heart Association/National Heart Lung, and Blood Institute scientific statement. Current Opinion in Cardiology 200621 1-6.

21 Bergman RN. Toward physiological understanding of glucose tolerance. Minimal-model approach. Diabetes $1989381512-1527$.

22 Boston RC, Stefanovski D, Moate PJ, Sumner AE, Watanabe RM \& Bergman RN. MINMOD millennium: a computer program to calculate glucose effectiveness and insulin sensitivity from the frequently sampled intravenous glucose tolerance test. Diabetes Technology and Therapeutics 20035 1003-1015.

23 Ohisalo JJ, Kaartinen JM, Ranta S, Mustajoki P, Hreniuk SP, LaNoue KF \& Martin LF. Weight loss normalizes the inhibitory effect of N6-(phenylisopropyl)adenosine on lipolysis in fat cells of massively obese human subjects. Clinical Science 199283 589-592.

24 Rodbell M. Metabolism of isolated fat cells. I. Effects of hormones on glucose metabolism and lipolysis. Journal of Biological Chemistry $1964239375-380$. 
25 Thorn CF, Lu ZY \& Whitehead AS. Regulation of the human acute phase serum amyloid A genes by tumour necrosis factor-alpha, interleukin-6 and glucocorticoids in hepatic and epithelial cell lines. Scandinavian Journal of Immunology 200459 152-158.

26 Santos-Alvarez J, Goberna R \& Sanchez-Margalet V. Human leptin stimulates proliferation and activation of human circulating monocytes. Cellular Immunology 1999194 6-11.

27 Fried SK, Bunkin DA \& Greenberg AS. Omental and subcutaneous adipose tissues of obese subjects release interleukin-6: depot difference and regulation by glucocorticoid. Journal of Clinical Endocrinology and Metabolism $1998 \mathbf{8 3} 847-850$.

28 Johnson BD, Kip KE, Marroquin OC, Ridker PM, Kelsey SF, Shaw LJ, Pepine CJ, Sharaf B, Bairey Merz CN, Sopko G, Olson MB \& Reis SE. National Heart, Lung, and Blood Institute. Serum amyloid A as a predictor of coronary artery disease and cardiovascular outcome in women: the National Heart, Lung, and Blood Institute-Sponsored Women's Ischemia Syndrome Evaluation (WISE). Circulation 2004 $109726-732$.

29 Wallace AM, McMahon AD, Packard CJ, Kelly A, Shepherd J, Gaw A \& Sattar N. Plasma leptin and the risk of cardiovascular disease in the west of Scotland coronary prevention study (WOSCOPS). Circulation $20011043052-3056$.

30 Wolk R, Berger P, Lennon RJ, Brilakis ES, Johnson BD \& Somers VK. Plasma leptin and prognosis in patients with established coronary atherosclerosis. Journal of the American College of Cardiology $2004 \mathbf{4 4}$ 1819-1824.
31 Abdullah SM, Khera A, Leonard D, Das SR, Canham RM, Kamath SA, Vega GL, Grundy SM, McGuire DK \& de Lemos JA. Sex differences in the association between leptin and CRP: results from the Dallas Heart Study. Atherosclerosis 2007195 404-410.

32 Shamsuzzaman AS, Winnicki M, Wolk R, Svatikova A, Phillips BG, Davison DE, Berger PB \& Somers VK. Independent association between plasma leptin and C-reactive protein in healthy humans. Circulation 2004109 2181-2185.

33 Kazumi T, Kawaguchi A, Hirano T \& Yoshino G. C-reactive protein in young, apparently healthy men: associations with serum leptin, QTc interval, and high-density lipoprotein-cholesterol. Metabolism 200352 1113-1116.

34 Anty R, Bekri S, Luciani N, Saint-Paul MC, Dahman M, Iannelli A, Amor IB, Staccini-Myx A, Huet PM, Gugenheim J, Sadoul JL, Le Marchand-Brustel Y, Tran A \& Gual P. The inflammatory $\mathrm{C}$-reactive protein is increased in both liver and adipose tissue in severely obese patients independently from metabolic syndrome, Type 2 diabetes, and NASH. American Journal of Gastroenterology $20061011824-1833$.

Received 20 November 2007

Accepted 10 December 2007 